\title{
Influence of Chitosan-Based Coatings with UV Irradiation on Quality of Strawberry Fruit During Cold Storage
}

\section{Erdinç Bal}

Department of Horticulture, Faculty of Agriculture, Tekirdă̆ Namık Kemal University, 59030 Tekirdağ, Turkey E-mail:ebal@nku.edu.tr, ORCID: https://orcid.org/0000-0001-9817-5842

\begin{tabular}{|c|c|}
\hline A R T I C L E I F O & A B S T R A C T \\
\hline $\begin{array}{l}\text { Keywords: } \\
\text { Strawberry } \\
\text { Anthocyanin } \\
\text { Ascorbic acid } \\
\text { Phenolics } \\
\text { Edible coating } \\
\text { Ultraviolet irradiation }\end{array}$ & $\begin{array}{l}\text { The objective of this work was to determine the effects of UV-C and chitosan coatings, alone or } \\
\text { in conjunction, on the quality of strawberry fruit during storage. The treated fruits were examined } \\
\text { for weight loss, respiration rate, soluble solids content, titratable acidity, ascorbic acid contents, } \\
\text { total anthocyanins, total phenolic contents, decay incidence and sensory analysis of strawberry } \\
\text { fruit were investigated during cold storage } 1 \pm 0.5^{\circ} \mathrm{C} \text { and } 90 \pm 5 \% \mathrm{RH} \text { for } 15 \text { days. The result showed } \\
\text { that chitosan coating with UV-C irradiation could further reduce decay incidence of strawberry } \\
\text { fruit, restrain increase of respiration rate and weight loss of strawberry fruit compared to other } \\
\text { treatments. Moreover, the total anthocyanins and total phenolic contents were maintained at higher } \\
\text { level, and the decrease of ascorbic acid was restricted during storage period. Likewise, sensory } \\
\text { analysis results also showed the effectiveness of UV-C }+ \text { chitosan treatment by retaining the } \\
\text { quality of strawberry fruit. Control and individual UV-C treatment had similar effects on } \\
\text { respiration rate and weight loss. The results showed that UV-C + chitosan treatment can be an } \\
\text { effective method for enhancing the phytochemical content and delaying fruit senescence of } \\
\text { strawberry fruit during cold storage. }\end{array}$ \\
\hline
\end{tabular}

(c) (1) (8) This work is licensed under Creative Commons Attribution 4.0 International License

\section{Introduction}

The maintenance of the quality of fresh produce is still a major challenge for the food industry. Demands of strawberry fruit from the supermarket require high-quality products with continuous supply (Risyahadi, 2015). Strawberry is a product appreciated by consumers due to the organoleptic characteristics (Brasil and Siddiqui, 2018). However, strawberry fruit have a very short shelf life due to their sensitivity to fungal attack and excessive texture softening caused by the natural ripening process after harvest, so alternative measures to prolong the shelf life of fruit are necessary (Stolfa et al., 2014).

Strawberry is a non-climacteric fruit characterized by a short postharvest life, often estimated for less than 5 days. Optimum storage conditions for strawberry fruit are $0^{\circ} \mathrm{C}$ and $90-95 \%$ relative humidity. In such conditions, strawberry fruit can have 7-10 days of storage life (Deak and Füstös, 2009). Low storage temperatures and modified atmospheres with elevated $\mathrm{CO}_{2}$ levels are common tools for minimizing mould growth, senescence, and extending the shelf life of strawberry fruit. However, prolonged exposure of strawberries to high $\mathrm{CO}_{2}$ concentrations can cause an 'off' flavor development (Ke et al., 1994; Nasrin et al., 2017).
Recently, biologically active natural products have started to become an effective alternative to synthetic fungicides (Hernandez-Munoz et al., 2008) and the concept of using edible coatings to extend the shelf life of fresh fruit and minimally processed products has been receiving considerable attention. Edible coatings based on natural materials form a promising safe and healthy tool for extending the shelf life of fresh agricultural products (Poverenov et al., 2014).

Edible coatings are natural polymers (such as proteins, lipids, and polysaccharides) obtained from products or by products of agricultural origin, such as animal and vegetable proteins, gums, lipids, and celluloses (Debeaufort et al., 1998). The main polysaccharides that can be included in edible coating formulations are starch and starch derivatives, cellulose derivatives, chitosan, pectin, alginate, and other gums (Ferreira et al., 2016). Edible coatings can act as moisture and gas barriers, control microbial growth, preserve the colour, retain biochemical compounds, texture and moisture of the product and can effectively extend the shelf life of the product (Kore et al., 2017). 
All fruit and vegetables have a natural waxy coating on their surface, which conserves water (Kore et al., 2017). However, strawberry fruit have a thin coating of skin and it must be supported for long-term storage. Therefore, finding suitable methods for preserving the quality of strawberry fruit during storage is important. The application of chitosan as a coating on strawberry fruit has shown immense potential to maintain the quality as well as extend the shelf life of them (Hernandez-Munoz et al., 2006; Vargas et al., 2006; Hernandez-Munoz et al., 2008; Gol et al., 2013; Nasrin et al., 2017). Furthermore, studies have shown that the combination of edible coatings with other preservative methods has achieved great success in quality maintenance in fresh produce. One of these methods is UV irradiation. The researches have shown that that use of a low dose of UV-C light $(254 \mathrm{~nm})$ is able to induce resistance of fruits and vegetables to postharvest storage rots (Nigro et al., 1998; Erkan et al., 2008), increasing the biosynthesis of several secondary metabolites and to delay the ripening process, extending the shelf life of fruits and vegetables (Stevens et al., 2004). Furthermore, studies have shown that the combination of UV-C with other preservative methods has achieved great success in quality maintenance in fresh produce (Lin et al., 2017). In jujubes, ultraviolet irradiation combined with chitosan coating was found to be effective method, and might be considered in commercial application for preservation of postharvest fruit (Zhang et al., 2014). Freitas et al. (2015) also reported that use of UV-C combined with chitosan coating before refrigerated storage increased the resveratrol content, maintained sensory quality, and reduced fungal decay of red table grapes when compared to control grapes.

The present study was conducted to investigate the effects of postharvest chitosan-based coating and UV irradiation treatments on fruit quality attributes and bioactive compounds of "Albion" strawberry cultivar during cold storage.

\section{Materials and Methods}

\section{Sample Preparation and Treatments}

Strawberry fruit (Fragaria $x$ ananassa cv. Albion) at commercial ripeness $(>75 \%$ of the surface showing red colour) were harvested from a green house in Kirklareli, Turkey. After harvesting, fruits were sorted to eliminate damaged fruit and selected for uniform size and color. Fruits in polypropylene bags were immediately transferred to the laboratory at the University of Tekirdag Namik Kemal under cold conditions and were divided into four groups ( 750 fruits per group and 3 replications / treatment). Treatments and abbreviations can be summarized as follows:

- Control: Fruits was immersed in distilled water at $20^{\circ} \mathrm{C}$ for 1 minute (min), and then dried for 2 hours (h) at ambient temperature.

- UV-C Irradiation: Fruits were irradiated using six germicidal, low-pressure vapor lamps (Osram HNS OFR). Each lamp ( $2.5 \mathrm{~cm}$ tube diameter; $88 \mathrm{~cm}$ length) had a nominal power output of $30 \mathrm{~W}$ and a peak wavelength emission of $253.7 \mathrm{~nm}$. The UV lamps (three lamps at the top and bottom) were assembled 15 $\mathrm{cm}$ apart and the UV-C field area under the lamps was
$60 \times 100 \mathrm{~cm}$ (Nigro et al., 1998). They were fixed at 25 $\mathrm{cm}$ above the sample placing spot and these were enclosed in a wooden box covered with aluminum foil. Fifteen min prior to use, the device was switched on for the purpose of stabilization. Then fruits were irradiated for $4 \mathrm{~min}$. After that fruits was immersed in distilled water at $20^{\circ} \mathrm{C}$ for 1 minute, and then dried for 2 hours at ambient temperature.

- Chitosan coating treatment: Chitosan solution was prepared according to Nasrin et al. (2017). For preparing $100 \mathrm{ml}$ of $2 \%$ chitosan solution, $2 \mathrm{~g}$ of chitosan (Sigma Chemical Co.), respectively, was dissolved in $75 \mathrm{ml}$ of distilled water and $2 \mathrm{ml}$ of glacial acetic acid was added. The mixture was heated with continuous stirring $\left(55^{\circ} \mathrm{C}\right)$ for proper dissolution of chitosan. The final $\mathrm{pH}$ of the solution was adjusted to 5.6 with $2 \mathrm{~N} \mathrm{NaOH}$ and the volume was made up to $100 \mathrm{ml}$ with sterilized distilled water. Fruits were submerged in these solutions, respectively, for 1 minute and allowed to dried for $2 \mathrm{~h}$ at ambient temperature.

- UV-C treatment followed by chitosan-based coating: Fruits were firstly irradiated $4 \mathrm{~min}$ at $253.7 \mathrm{~nm}$ ultraviolet over $25 \mathrm{~cm}$ height of single layer strawberry fruit, and then they were wholly dipped into $2 \%$ of chitosan solution for $1 \mathrm{~min}$. Afterward the strawberries were taken out and dried for $2 \mathrm{~h}$ at ambient temperature.

The treated fruits were sealed in polypropylene bags $(0.250 \mathrm{~kg})$ and stored at $1 \pm 0.5{ }^{\circ} \mathrm{C}$ and $90 \pm 5 \%$ relative humidity $(\mathrm{RH})$ for 15 days. Measurements of all parameters started at the beginning of the storage and then continued until the day of 15 with 3 days intervals.

\section{Analysis of Quality Attributes}

Weight loss: Fruit weights were determined using a $0.01 \mathrm{~g}$ sensitive digital scale (Radvag WLC/6/A2, Poland). Weight loss during storage was determined by measuring the fruit weight before and after the storage period and was expressed as the percentage of weight loss with respect to the initial weight.

Respiration rate: Respiration rate in strawberries was recorded in the headspace of the container using an auto gas analyzer (Systech Gaspace advance GS3L). The individual fruit was enclosed in a hermetic container for 30 min (stored at $1^{\circ} \mathrm{C}$ and $90 \% \mathrm{RH}$ ) and from the headspace gas, concentration of $\mathrm{CO}_{2}$ was measured by piercing the probe of auto gas analyzer in the container through the septa fixed on the lid of container and direct reading was noted from instrument screen. The $\mathrm{CO}_{2}$ evolution was calculated in $\mathrm{ml}$ of $\mathrm{CO}_{2} \mathrm{~kg}^{-1} \mathrm{~h}^{-1}$ by using formula (Demirdoven and Batu, 2004).

Total soluble solids, titratable acidity and ascorbic acid contents: For the analysis of total soluble solids (TSS) content and titratable acidity (TA) of each sample, tissue sap was squeezed out from fresh fruit materials with a press. In the juice, SSC were determined with a hand refractometer (\%) (Atago Co. Ltd., Japan). TA content was determined by titration method and calculating the result as grams of citric acid per $100 \mathrm{~g}$ fresh weight. Ascorbic acid content was measured using 2,5-6 dicholorophenol indophenols' method described by A.O.A.C (1990) and expressed as mg $100 \mathrm{~g}^{-1}$. 
Total anthocyanins and total phenolic contents: Total anthocyanin content of the strawberry extracts was measured using the $\mathrm{pH}$ differential method (Cheng and Breen, 1991). Results were expressed as milligrams of pelargonidin 3-glucoside equivalents per $100 \mathrm{~g}$ of fresh weight.

For the total phenolics assay, the ethanol extract of fruit was added to $2.0 \mathrm{ml}$ of $1 \mathrm{~mol} \mathrm{\textrm {l } ^ { - 1 }}$ Folin-Ciocalteau reagent. After mixing thoroughly for $5 \mathrm{~min}, 1.5 \mathrm{ml}$ of $7.5 \% \mathrm{Na}_{2} \mathrm{CO}_{3}$ solution was added into the mixture. The mixtures were then incubated for $1 \mathrm{~h}$ at room temperature in the dark and the absorbance was measured at $765 \mathrm{~nm}$. Results were expressed as milligrams of gallic acid equivalent per $100 \mathrm{~g}$ of fresh weight (Liu et al., 2018).

\section{Decay Incidence}

Decay incidence of strawberry fruit was the number of fruit showing decay symptoms (rot, lesions or visible fungal growth) relative to the total number of fruit and expressed in percentage $(\%)$.

\section{Sensory Analysis}

Sensory evaluation, based on general visual appeal, colour and visible structural integrity, was conducted using a 7-point hedonic scale by a six member panel. The scores were: like extremely (7); like very much (6); like moderately (5); neither like nor dislike, marketable (4), dislike moderately (3); dislike very much (2); and dislike extremely (1). Fruit scored above 4 was considered acceptable. Only fruits lacking signs of fungal decay were evaluated (Hernandez-Munoz et al., 2008).

\section{Statistical Analysis}

The experiment was of a completely randomized factorial design of three replications per treatment. Analysis of variance (ANOVA) was the means for analyzing the difference between means and while LSD test being applied for mean separation at $\mathrm{P}<0.05$. All the analyses were carried out through SPSS as statistical software. Results are reflected as the mean \pm SE.

\section{Results and Discussion}

\section{Weight Loss}

The thin skin of strawberry fruit make them susceptible to rapid water loss, resulting in shriveling, dryness of the calyx and darkening red color. Edible coatings act as barriers, thereby restricting water transfer and protecting fruit skin from mechanical injuries, as well as sealing small wounds and thus delaying dehydration (HernanadezMunoz et al., 2008). The result of treatments on fruit weight loss is shown in Fig. 1. Weight loss of treated and untreated fruits increased during storage. The loss of weight in uncoated fruit was significantly greater than that in coated fruit. UV-C irradiation alone did not affect weight loss of fruit. However, UV-C irradiation also did not produce adverse effect on chitosan coating. After 9 days of storage the loss of weight of fruit was around $7 \%$ higher for control and UV-C treated fruits compared to coated samples. At the end of the storage, the highest weight loss was determined in control fruits $(16 \%)$, while the lowest weight loss was determined in UV-C + chitosan treatment (7.2\%) followed by chitosan treatment $(8 \%)$. These results are consistent with those of previous studies demonstrating that chitosan coating acts as a semipermeable barrier against oxygen, carbon dioxide and moisture, thereby reducing respiration and water loss and counteracting the dehydration and shrinkage of the fruit (Hernandez-Munoz et al., 2008; Petriccione et al., 2015; Nasrin et al., 2017).

\section{Respiration Rate}

Edible coating treatments have the potential of reducing respiration rate of fruits due to blocking pores of the peel and lessen permeability to water vapor and gas exchanges. Reduction of the respiration rate as a result of coatings has been reported in coated fresh produces (Lin et al., 2017). In the study, coated strawberries presented a significantly lower $\mathrm{CO}_{2}$ emission rate than the uncoated fruits (Fig 2). This result is in agreement with previous studies on strawberry fruit (Vargas et al., 2006; HernandezMunoz et al., 2008; Nasrin et al., 2017), showed that respiration rate of coated fruits was significantly lower than control under cold storage. The tendency of higher water loss of uncoated strawberry fruit was accompanied with the increase of respiration rate during cold storage (Figs 1 and 2 ). Although fluctuations in the respiration rate were observed, an increase towards the end of storage was detected in all treatments. This increase of respiration rate could be related to fruit senescence and disease development. At the end of 15 days, the highest respiration rate was determined in control fruits $\left(52.1 \mathrm{mg} \mathrm{CO}_{2} \mathrm{~kg}^{-1} \mathrm{~h}^{-1}\right)$ followed by UV-C treatment (48.3 mg CO $2 \mathrm{~kg}^{-1} \mathrm{~h}^{-1}$ ) and lowest respiration rate was determined in UV-C + chitosan treated fruits $\left(31.2 \mathrm{mg} \mathrm{CO}_{2} \mathrm{~kg}^{-1} \mathrm{~h}^{-1}\right)$ followed by chitosan (33.6 mg CO $\mathrm{kg}^{-1} \mathrm{~h}^{-1}$ ) treated fruits. UV-C treatment did not significantly affect the respiration rate as a similar effect was demonstrated in weigh loss of strawberry fruit.

\section{TSS and TA Content}

Both TSS and TA contents directly were related with strawberry taste and sensory quality. During storage, all strawberries showed an increase in TSS and then decrease in TA, which may reflect the process from commercial maturity to over-ripeness. The change in TSS content of strawberries as a function of storage time is shown in Fig 3. No significant difference in TSS content was observed between untreated and treated fruits within the first $6 \mathrm{~d}$ of storage. Between day 9 and 15, chitosan and UV-C + chitosan treatments proved significantly beneficial in maintaining higher levels of TSS in strawberries compared to other treatments. At end of 15 days of storage, the highest TSS content was recorded in control (11.9\%) followed by UV-C treatment $(11.8 \%)$ while lowest TSS content was recorded respectively chitosan treatment $(10.3 \%)$ and UV-C + chitosan treatment $(10.6 \%)$. The low increase in TSS values for the chitosan-coated fruits might reflect changes in the internal atmosphere of the fruit, with a reduction in the $\mathrm{O}_{2}$ level and/or an increase in the $\mathrm{CO}_{2}$ level, which reduce the respiration rate and metabolic activity, such as the conversion of sugars into $\mathrm{CO}_{2}$ and $\mathrm{H}_{2} \mathrm{O}$ (Ghasemnezhad et al., 2011; Petriccione et al. 2015). Moreover, the greater changes in TSS occurred in those strawberries which suffered the greatest water loss. These results are also in line with the results reported by Hernandez-Munoz et al. (2006) and Gol et al. (2013) who assigned the probable reasons for the reducing levels of TSS accumulation in the chitosan coated fruit to the slowing down of respiration and metabolic activity. 


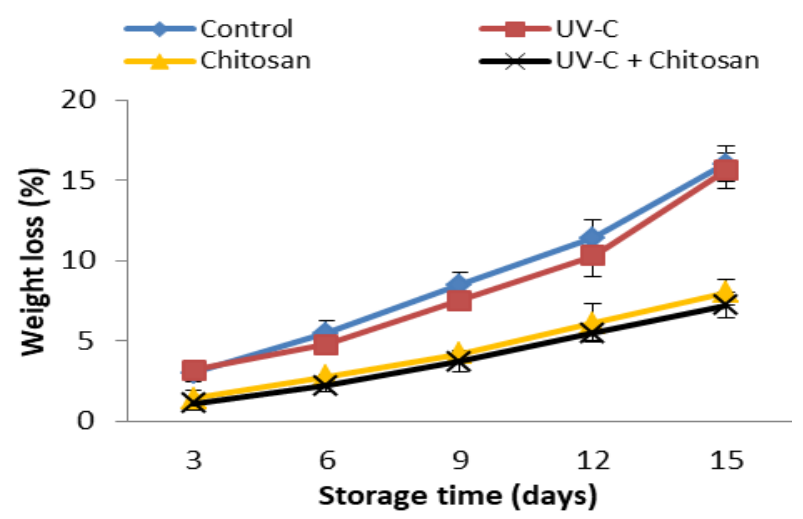

Figure 1 Effect of ultraviolet irradiation and chitosan coating on weight loss of strawberries fruit during storage

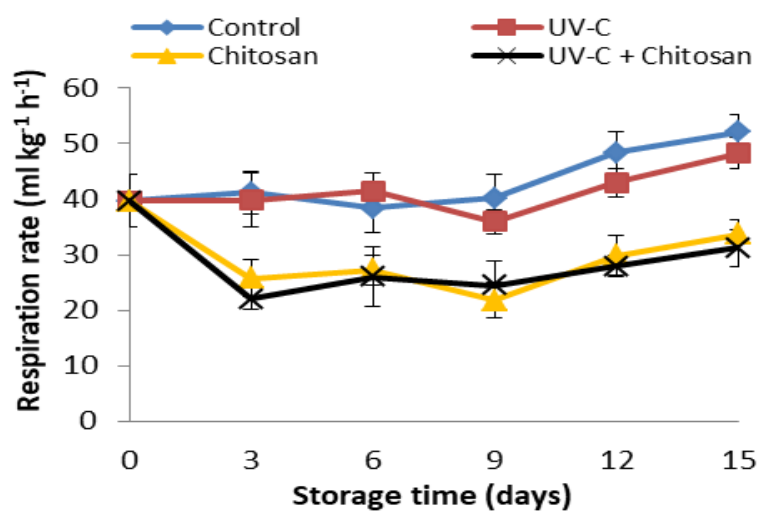

Figure 2 Effect of ultraviolet irradiation and chitosan coating on respiration rate of strawberries during cold storage

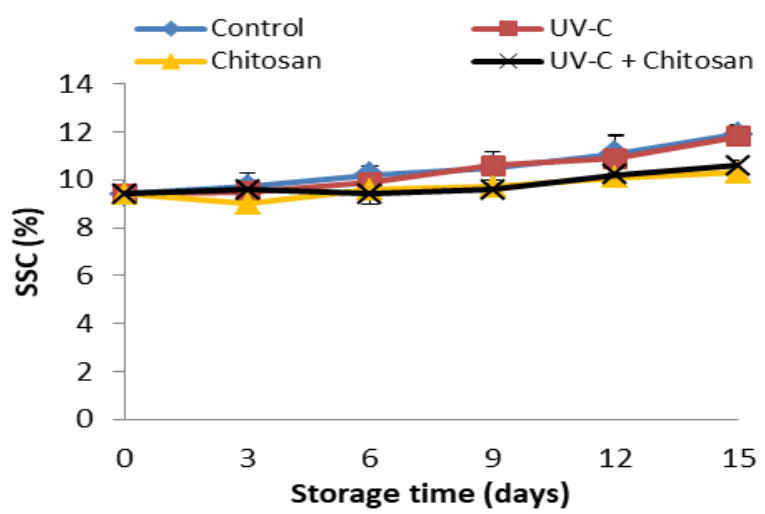

Figure 3 Effect of ultraviolet irradiation and chitosan coating on SSC of strawberries during cold storage

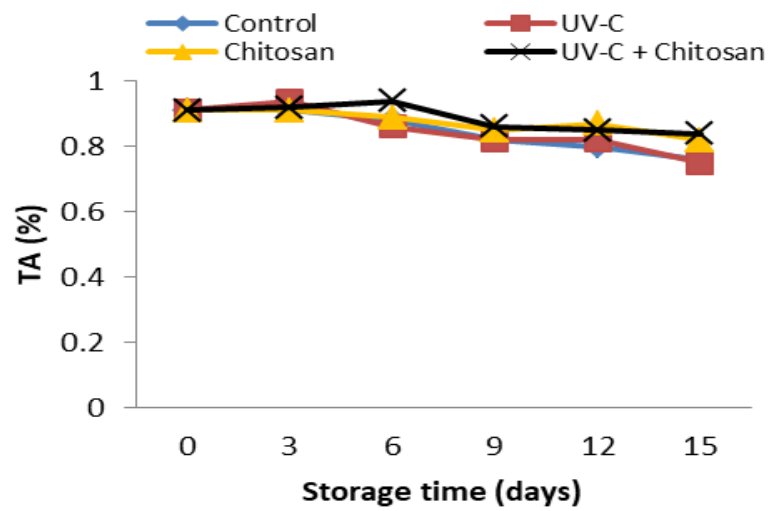

Figure 4 Effect of ultraviolet irradiation and chitosan coating on TA of strawberries during cold storage
A decrease in organic acid is typical during postharvest storage of strawberry fruit (Koyuncu and Dilmacunal, 2010) and has been attributed to the use of organic acids as substrates for respiratory metabolism (Valero and Serrano, 2010). In the study, TA decreased during the storage period in all treatments. However, no significant changes were observed in TA during storage between control and other treated strawberries (Fig 4).

\section{Ascorbic acid Contents}

Ascorbic acid is important health-beneficial compounds in strawberry fruit. In the present study, the initial content of ascorbic acid was $38.6 \mathrm{mg} 100 \mathrm{~g} \mathrm{~g}^{-1}$ of fresh fruit. The results illustrated in (Fig 5) revealed that there was a significant decrease in ascorbic acid values of fruits along with the storage period. The decreased in ascorbic acid content in the $15^{\text {th }}$ day of storage can be attributed to the loss of water from fruits due to the respiration and microbial growth (Hernandez-Munoz et al., 2008). The UV-C treatment did not contribute to ascorbic acid preservation. However, combining UV-C and chitosan treatments produced significantly retarded ascorbic acid degradation compared to UV-C treatment alone or control. At the end of cold storage, the lowest ascorbic acid value

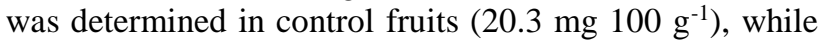
the highest ascorbic acid value was determined in UV-C + chitosan treatment $\left(29.9 \mathrm{mg} 100 \mathrm{~g} \mathrm{~g}^{-1}\right)$ followed by chitosan treatment $\left(26.8 \mathrm{mg} 100 \mathrm{~g}^{-1}\right)$. The lowering of vitamin $\mathrm{C}$ loss of fruit with coatings containing antioxidants can be attributed to the low oxygen permeability of these coatings delays the deteriorative oxidation reaction of ascorbic acid in strawberry fruit (Sogvar et al., 2016). Reduction in the ascorbic acid content was also reported during storage of strawberry cv. Camarosa (Gol et al., 2013) and cv. Bar1 (Nasrin et al., 2017) in coated strawberries.

\section{Total Anthocyanins}

The attractive red color of strawberries is due to elevated levels of anthocyanin pigments (Howard et al., 2014). In the present study, total anthocyanin content at harvest was $53.2 \mathrm{mg} 100 \mathrm{~g}^{-1}$ and increased in all applications up to 12 days compared to the initial value (Fig 6). However, the coated plums displayed a significant delay in the rate of increase in anthocyanin content. Similar pattern of initial increase in anthocyanins followed by decrease after prolonged storage of strawberry fruit has been reported by other authors also (Zheng et al., 2007; Dhital et al., 2018). At the end of the storage, the increases in chitosan $\left(65.1 \mathrm{mg} 100 \mathrm{~g}^{-1}\right)$ and UV-C + chitosan (63.5 mg $\left.100 \mathrm{~g}^{-1}\right)$ treatments continued, but there was a sharp decline in control $\left(51.8 \mathrm{mg} 100 \mathrm{~g}^{-1}\right)$ and UV-C (57.6 mg $\left.100 \mathrm{~g}^{-1}\right)$ treatments. These findings could be attributed to the action of gum arabic coatings, which act as a gas barrier, hence modifying the internal atmosphere in the fruit and this in turn may delay the biochemical reactions leading to in anthocyanin synthesis (Tahir et al., 2018). Similar results were observed by (Gol et al., 2013), who reported that chitosan coating can significantly retard anthocyanin synthesis. Control fruit and alone UV-C treated fruits could be considered as over-ripe and in senescence phase, at which a drastic diminution of total anthocyanins occurred. Hence, the strawberry fruit became redder and darker along with increased storage time, result of which is similar to that reported by Han et al. (2004). 


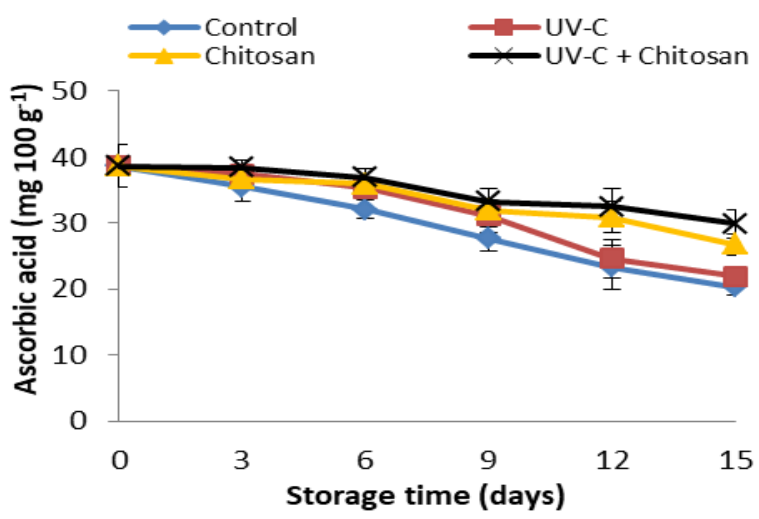

Figure 5 Effect of ultraviolet irradiation and chitosan coating on ascorbic acid of strawberries during cold storage

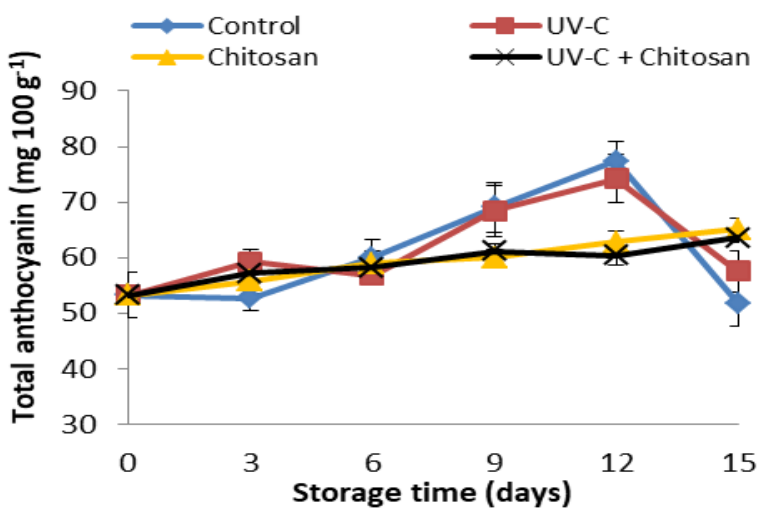

Figure 6 Effect of ultraviolet irradiation and chitosan coating on total anthocyanin content of strawberries during cold storage

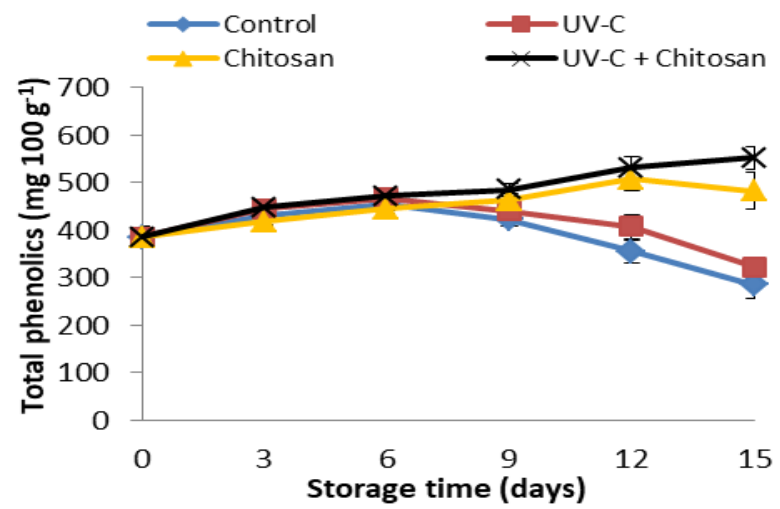

Figure 7 Effect of ultraviolet irradiation and chitosan coating on total phenolic content of strawberries during storage

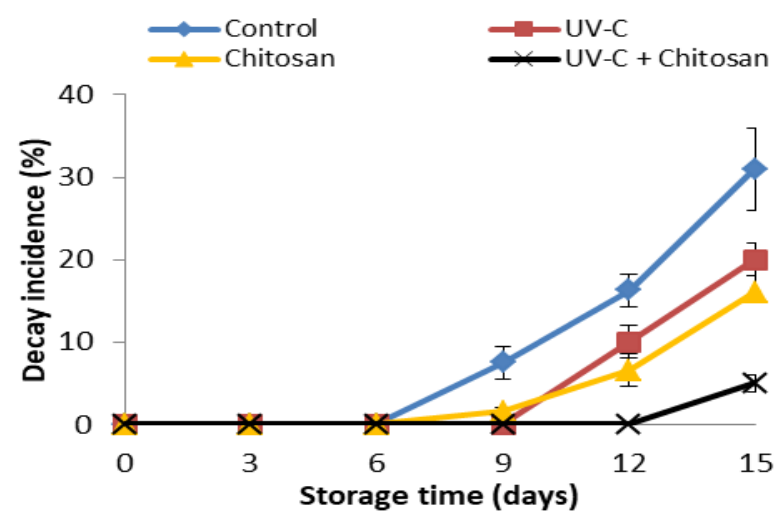

Figure 8 Effect of ultraviolet irradiation and chitosan coating on decay incidence of strawberries during cold storage

\section{Total Phenolic Contents}

Phenolic compounds are secondary metabolites widely found in fruits (Haminiuk et al., 2012). In the study, phenolic compounds of strawberries are presented in Fig 7 and were $198.4 \mathrm{mg} 100 \mathrm{~g}^{-1}$ at harvest. Total phenolic contents initially exhibited a slight increase in all treated fruits between day 0 and day 6 of storage. However, this trend was followed by significant decreases from day 9 through day 15 in control and UV-C treatments. The highest phenolic content was found with UV-C + chitosan

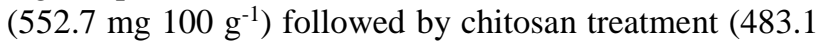
$\left.\mathrm{mg} 100 \mathrm{~g}^{-1}\right)$ and the lowest one was found in control (285.4 $\mathrm{mg} 100 \mathrm{~g}^{-1}$ ) followed by UV-C treatment (322.4 mg $100 \mathrm{~g}^{-1}$ ) after $15 \mathrm{~d}$ storage. These results are consistent with previous studies demonstrating that chitosan treatment improved the nutraceutical properties of strawberry fruit, maintaining high levels of phenols, anthocyanins and flavonoids during postharvest (Wang and Gao, 2013; Petriccione et al., 2015). The use of UV-C with chitosan coating showed as a positive effect in maintaining higher concentration of total phenolics. This result is in line with the findings of Lin et al. (2017) who reported that UV treatment combined with chitosan coating was found to be effective treatment for reducing total phenolics content of longan fruit. The rises in phenolic levels may be due to general abiotic stresses which affect the pathways involved in biosynthesis of the secondary metabolites (CisnerosZevallos, 2003). Moreover, the decrease in total soluble phenolics observed in the present study might be at least partly a consequence of the degradation of anthocyanins. Actually, relative losses in total anthocyanins were similar to losses in total phenolic content within each treatment.

\section{Decay Incidence}

Strawberry fruit is an highly perishable fruit mainly due to their soft texture and sensitivity to fungal infection by Botrytis cinerea which is the main causal agent of postharvest decay and subsequent economic loss (Naradisorn, 2008). In the present study, the results showed that decay was observed for the first time after $9 \mathrm{~d}$ of storage in the control and chitosan treated strawberry fruit, after that, decay incidence increased as storage time progressed (Fig 8). UV-C + chitosan significantly reduced the yeast and mould count of strawberry fruit and decay was found only in the $15^{\text {th }}$ day. At the end of the storage, the highest decay rate was determined in control fruits (31 $\%$ ) and lowest decay rate was determined in UV-C + chitosan treated fruits $(5 \%)$ followed by chitosan (16\%) and UV-C (20\%) treated fruits. UV irradiation and capacity of chitosan coating to inhibit the growth of several fungi has been found successfully for a wide variety of harvested commodities (Nigro et al., 1998; Erkan et al., 2008; Bal, 2013; Kore et al., 2017). Towards the end of storage, less decay in fruits treated with UV irradiation in combination with chitosan coating was attributed to the synergistic effect of the treatments on delaying the appearance of mould growth and other physiological processes like respiration and senescence. Similarly, Romanazzi et al. (2006) reported that combined chitosan and UV-C treatments applied to cv. Autumn Black or selection B3655 were synergistic in reducing gray mold incidence and severity compared with either treatment alone. Vachon et al. (2003) and Hussain et al. (2012) also reported that 
combinatory treatment of gamma irradiation and coating was found significantly effective compared with other treatments in maintaining the quality and delaying the decay and appearance of the fungal growth in strawberry.

\section{Sensory Analysis}

Loss of quality in strawberry fruit is mostly due to its relatively high metabolic activity and sensitivity to fungal decay. Strawberry fruit is also susceptible to water loss, bruising and mechanical injuries due to their soft texture and lack of a protective rind (Hernandez-Munoz et al., 2006). Results of the sensory quality analysis using a 7point hedonic scale are shown in Fig 9. Throughout the storage time, all the fruit showed a loss of sensory quality. However, coating treatments did not alter strawberry colour and the greater acceptance for coated fruit could be due to the glossy appearance imparted by the coating that is in line with those of Nasrin et al. (2017). The sensory attributes evaluated for strawberries were acceptable (over 4 point) in all applications until day 9 of storage. Due to the rapid weight loss, increasing decay rate and color darkness, the control ( 2.8 point) and UV-C ( 3 point) treated fruits was become unacceptable at $12^{\text {th }}$ day of storage. At the end of the storage, UV-C + chitosan treatment was more effective in retarding sensory deterioration of strawberries and only this treatment were found to be marketable. The synergistic effect of combination treatment on inhibition of fungal growth, retention of texture and colour proved significantly beneficial in maintaining higher overall acceptability of treated strawberries compared other treatments during storage (Hussain et al., 2012). Similarly, Freitas et al. (2015) reported that use of UV-C combined with chitosan coating maintained sensory quality and reduced fungal decay of red table grapes.

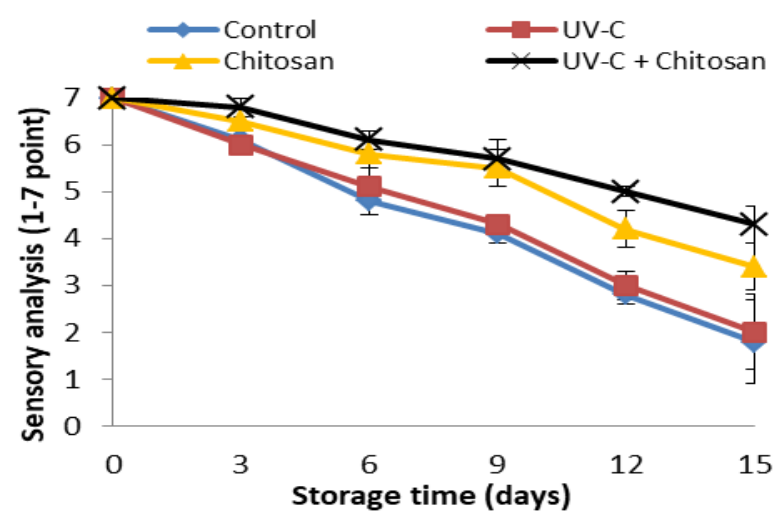

Figure 9 Effect of ultraviolet irradiation and chitosan coating on sensory analysis of strawberries during cold storage

\section{Conclusion}

As a result, UV-C irradiation combined with chitosan coating was suggested to be an effective method to retard postharvest strawberries ripening process demonstrated by reducing many physiological changes and delaying fungal growth. The results of the study showed that the effectiveness of combined treatment for postharvest 'Albion' strawberry fruit preservation up to 15 days at $1 \pm 0.5^{\circ} \mathrm{C}$ and $90 \pm 5 \% \mathrm{RH}$.

\section{References}

A.O.A.C. 1990. Official methods of analysis of the association of official analytical chemists, 15th ed., Association of Official Analytical Chemists, Arlington VA, pp. 1058-1059.

Bal E. 2013. Postharvest application of chitosan and low temperature storage affect respiration rate and quality of plum fruits. J Agri. Sci. and Tech., 15(6): 1219-1230.

Brasil IM, Siddiqui M. 2018. Postharvest quality of fruits and vegetables: An overview. In: Siddiqui, M.W. (Ed.), Preharvest modulation of postharvest fruit and vegetable quality, Elsevier, USA.

Cisneros-Zevallos L. 2003. The use of controlled postharvest abiotic stresses as a tool for enhancing the nutraceutical content and adding-value of fresh fruits and vegetables. J. Food Sci., 68: 1560-1565. DOI: 10.1111/j.13652621.2003.tb12291.x

Deak S, Füstös Z. 2009. Shelf life and storage of strawberry varieties. PTEP 13(3): 229-231.

Debeaufort F, Quezada-Gallo JA, Voilley A. 1998. Edible films and coatings: tomorrow's packaging: a review. Critical Reviews in Food Science and Nutrition, 38: 299-313. DOI: 10.1080/10408699891274219.

Demirdoven A, Batu A. 2004. Respiration rates of some important fruits grown in Tokat. GTED, 17: 33-37.

Dhital R, Mora NB, Watson D, Kohli P, Choudhary R. 2018. Efficacy of limonene nano coatings on postharvest shelf life of strawberries. LWT-Food Sci. Technol. 97: 124-134. DOI: 10.1016/j.lwt.2018.06.038.

Erkan M, Wang SY, Wang CY. 2008. Effect of UV treatment on antioxidant capacity, antioxidant enzyme activity and decay in strawberry fruit. Postharvest Biol. Technol., 48: 163-171. DOI: 10.1016/j.postharvbio.2007.09.028.

Ferreira AR, Vítor DA, Coelhoso IM. 2016. Polysaccharidebased membranes in food packaging applications. Membranes, 6(2): 1-17. DOI: 10.3390/membranes6020022.

Freitas PM, Lopez-Galvez F, Tudela JA, Gil MI, Allende A. 2015. Postharvest treatment of table grapes with ultraviolet$\mathrm{C}$ and chitosan coating preserves quality and increases stilbene content. Postharvest Biol. Technol., 105: 51-57. DOI: 10.1016/j.postharvbio.2015.03.011.

Ghasemnezhad M, Nezhad MA, Gerailoo S. 2011. Changes in postharvest quality of loquat (Eriobotrya japonica) fruits influenced by chitosan. Hort. Environ. Biotechnol. 52: 40-45.

Gol NB, Patel PR, Rao TVR. 2013. Improvement of quality and shelf-life of strawberries with edible coatings enriched with chitosan. Postharvest Biol. Technol., 85: 185-195. DOI: 10.1016/j.postharvbio.2013.06.008.

Haminiuk CWI, Maciel GM, Plata-Oviedo MSV, Peralta RM. 2012. Phenolic compounds in fruits - An overview. Int. J. Food Sci. Technol., 47(10): 2023-2044.

Han C, Zhao Y, Leonard SW, Traber MG. 2004. Edible coatings to improve storability and enhance nutritional value of fresh and frozen strawberries (Fragaria $x$ ananassa) and raspberries (Rubus ideaus). Postharvest Biol. Technol., 33: 67-78.

Hernandez-Munoz P, Almenar E, Ocio MJ, Gavara R. 2006. Effect of calcium dips and chitosan coatings on postharvest life of strawberries (Fragaria x ananassa). Postharvest Biol. Technol., 39: 247-253.

Hernandez-Munoz P, Almenar E, Del Valle V, Velez D, Gavara R. 2008. Effect of chitosan coating combined with postharvest calcium treatment on strawberry (Fragaria ananassa) quality during refrigerated storage. Food Chem., 110(2): 428-435. DOI: 10.1016/j.foodchem.2008.02.020.

Howard LR, Brownmiller C, Prior RL. 2014. Improved color and anthocyanin retention in strawberry puree by oxygen exclusion. J. Berry Res., 4(2):107-116. 
Hussain PR, Dar MA, Wani AM. 2012. Effect of edible coating and gamma irradiation on inhibition of mould growth and quality retention of strawberry during refrigerated storage. Int. J. Food Sci. Technol., 47(11): 2318-2324. DOI: 10.1111/j.1365-2621.2012.03105.x

Ke D, Zhou L, Kader AA. 1994. Mode of oxygen and carbon dioxide action on strawberry ester biosynthesis. J. Amer. Soc. Hort. Sci. 119:971-975.

Kore VT, Tawade SS, Kabir J. 2017. Application of edible coatings on fruits and vegetables. Imperial Journal of Interdisciplinary Research, 3(1): 591-603.

Koyuncu MA, Dilmacunal T. 2010. Determination of vitamin c and organic acid changes in strawberry by HPLC during cold storage. Notulae Botanicae Horti AgrobotaniciCluj-Napoca 38(3): 95-98.

Lin MG, Lasekan O, Saari N, Khairunniza S. 2017. The effect of the application of edible coatings on or before ultraviolet treatment on postharvested longan fruits. Hindawi Journal of Food Quality, 2017:1-11. DOI: 10.1155/2017/5454263.

Liu C, Zheng H, Sheng K, Liu W, Zheng L. 2018. Effects of melatonin treatment on the postharvest quality of strawberry fruit. Postharvest Biol. Technol., 139: 47-55. DOI: 10.1016/j.postharvbio.2018.01.016.

Naradisorn M. 2008. Effect of nutrition on postharvest quality and grey mould development in strawberries, Ph. D. Dissertation, University of Adelaide, South Australia, Australia.

Nasrin TAA, Rahman MA, Hossain MA, Islam MN, Arfin MS. 2017. Postharvest quality response of strawberries with aloe vera coating during refrigerated storage. J. Horticultural Sci. Biotech., 92(6): 598-605. DOI: 10.1080/14620316.2017.1324326.

Nigro F, Ippolito A, Lima G. 1998. Use of UV-C to reduce storage rot of table grape. Postharvest Biol. Technol., 13: 171181.

Petriccione M, Mastrobuoni F, Pasquariello MS, Zampella L, Nobis E, Capriolo G, Scortichini M. 2015. Effect of chitosan coating on the postharvest quality and antioxidant enzyme system response of strawberry fruit during cold storage. Foods, 4: 501-523.

Poverenov E, Zaitsev Y, Arnon H, Granit R, Alkalai-Tuvia S, Perzelan Y, Weinberg T, Fallik, E. 2014. Effects of a composite chitosan-gelatin edible coating on postharvest quality and storability of red bell peppers. Postharvest Biol. Technol., $\quad 96:$ 106-109. 10.1016/j.postharvbio.2014.05.015.

Risyahadi ST. 2015. Scheduling model in strawberry harvesting by considering product decay during storage. Proc. Manuf. 4 , 487-495.
Romanazzi G, Mlikota Gabler F, Smilanick JL. 2006. Preharvest chitosan and postharvest UV irradiation treatments suppress gray mold of table grapes. Plant Disease 90: 445-450.

Sogvar,OB, Saba MK, Emamifar A. 2016. Aloe vera and ascorbic acid coatings maintain postharvest quality and reduce microbial load of strawberry fruit. Postharvest Biol. Technol., 114: 29-35. DOI: 10.1016/j.postharvbio.2015.11.019.

Stevens C, Liu J, Khan VA, Lu JY, Kabwe MK., Wilson CL, Igwegbe ECK, Chalutz E, Droby S. 2004. The effects of lowdose ultraviolet light-C treatment on polygalacturonase activity, delay ripening and Rhizopus soft rot development of tomatoes. Crop Protection 23: 551-554.

Stolfa I, Maric S, Maric S, Stanisavljevic A, Vukovic R, Spoljaric D, Varga M. 2014. The impact of environmentally friendly postharvest treatments on the antioxidant activity of strawberry fruits during storage. Poljoprivreda, Agriculture, 20(2): 23-28.

Tahir HE, Xiaobo Z, Jiyong S, Mahunu GK., Zhai X, Mariod AA. 2018. Quality and postharvest-shelf life of cold-stored strawberry fruit as affected by gum arabic (Acacia senegal) edible coating. J Food Biochem., 42: 1-10. DOI: $10.1111 /$ jfbc. 12527.

Vachon C, D'Aprano G, Lacroix M, Letendre M. 2003. Effect of edible coating process and irradiation treatment of strawberry (Fragaria spp.) on storage keeping quality. J. Food Sci., 68: 608-612.

Valero D, Serrano M. 2010. Postharvest Biology and Technology for Preserving Fruit Quality. CRC Press, 287.

Vargas M, Albors A, Chiralt A, Gonzalez-Martinez C. 2006. Quality of cold-stored strawberries as affected by chitosanoleic acid edible coatings. Postharvest Biol. Technol., 41(2): 164-171.

Wang SY, Gao H. 2013. Effect of chitosan-based edible coating on antioxidants, antioxidant enzyme system, and postharvest fruit quality of strawberries (Fragaria $\times$ ananassa Duch.). LWT-Food Sci. Technol., 52: 71-79. DOI: 10.1016/j.lwt.2012.05.003.

Zhang SY, Yu YW, Xiao CL, Wang XD, Lei YF. 2014. Effect of ultraviolet irradiation combined with chitosan coating on preservation of jujube under ambient temperature. LWTFood Sci. Technol. 57(2): 749-754. DOI: 10.1016/j.lwt.2014.02.046.

Zheng Y, Wang SY, Wang CY, Zheng W. 2007. Changes in strawberry phenolics, anthocyanins and antioxidant capacity in response to high oxygen treatments. LWT-Food Sci. Technol. 40: 49-57. DOI: 10.1016/j.lwt.2005.08.013. 